\title{
Infrastructural and Social Aspects of ICT Dissemination in Rural Areas in Ukraine in Juxtaposition with Other Post-Transition Countries-State of Play and Prospects for Rural Development
}

\author{
Aleksandra Synowiec (D)
}

check for updates

Citation: Synowiec, Aleksandra. 2021 Infrastructural and Social Aspects of ICT Dissemination in Rural Areas in Ukraine in Juxtaposition with Other Post-Transition Countries-State of Play and Prospects for Rural Development. Journal of Risk and Financial Management 14: 16. https:// doi.org/10.3390/jrfm14010016

Received: 8 November 2020 Accepted: 22 December 2020 Published: 1 January 2021

Publisher's Note: MDPI stays neutral with regard to jurisdictional clai$\mathrm{ms}$ in published maps and institutional affiliations.

Copyright: () 2021 by the author. Licensee MDPI, Basel, Switzerland. This article is an open access article distributed under the terms and conditions of the Creative Commons Attribution (CC BY) license (https:// creativecommons.org/licenses/by/ $4.0 /)$.
Department of Applied Social Sciences, Faculty of Organization and Management, Silesian University of Technology, 41-800 Zabrze, Poland; aleksandra.synowiec@polsl.pl

\begin{abstract}
The objective of this study is to identify the current state of, and the prospects for, information and communication technologies (ICT) dissemination in rural areas in Ukraine in juxtaposition with other post-transition countries. The spread of ICT is discussed within the frame of economic, infrastructural, and social factors affecting rural areas in Ukraine since the post-communist transition period. Information and communication technologies may support the socio-economic development of peripheral areas in many ways-including rural ones. Dissemination of ICT contributes to the emergence of sources of income, equalizes education opportunities, and increases the attractiveness of rural areas. However, the rural-urban divide in the countries of Central and Eastern Europe and other former USSR countries is still remarkable and, as a type of structural inequality, should be better recognized. The source material is based on secondary data, which consists of selected literature on the subject of rural development in Central and Eastern European Countries, strategic documents, available reports and studies of international institutions, research from agencies, state documents and statistics, and research conducted by international and domestic NGOs. In reference to the paper's objective, the method of content analysis was employed. Dissemination of ICT in rural areas in Ukraine is influenced by two groups of factors. The infrastructural divide concerning Internet access between rural and urban populations in Ukraine has been diminishing, but the issue of structural exclusion due to place of residence has still not been solved. As far as the social aspects of ICT dissemination in rural areas in Ukraine are concerned, the level of digital literacy among rural dwellers is significantly lower in comparison to urban residents. Rural areas are more exposed to the consequences of various aspects of digital exclusion.
\end{abstract}

Keywords: rural areas; information and communication technologies; socio-economic development; digital divide; social change

\section{Introduction}

Regardless that the core of modernization and development discourse addresses mostly urban areas, it should not be forgotten that, according to the European classification of territorial units standardized in the Nomenclature of Territorial Units for Statistics (NUTS), rural areas account for over $90 \%$ of the area of EU countries and are inhabited by $60 \%$ of the total EU population (Kaleta 2016). In 2015, almost one quarter $(22.8 \%$ ) of the EU-28 population was living in a rural area (Eurostat 2018). However, in the social sciences the discourse on progress and development is focused mainly on the analysis and description of dynamically emerging cities (Kaleta 2016, p. 35). Rural areas, likewise, face up to challenges related to the grand societal shift from the productive to the post-productive economy and the spread of information and communication technologies (ICT) is undoubtedly one of the most important aspects of a new paradigm of development. Growing interest both in regional and international policies concerning rural areas indicates the 
importance of rural development (Grimes 2003; Bogovic and Szanyi 2018; Guzal-Dec 2018; Kaleta 2016; Cowie et al. 2020). The undertaken research question concerning the economic, infrastructural, and social contexts of dissemination of ICT in rural areas in Ukraine in comparison to other post-transition countries is important also from the perspective of expanding knowledge on the social changes taking place in the post-communist states, including the problem of the digital divide. This paper is an attempt to investigate and highlight the impact of infrastructural and social factors on the dissemination of ICT in rural areas in Ukraine. Post-transformation countries are understood as the countries of Central and Eastern Europe (CEE) and the countries of the former USSR, which have undergone a structural and economic transition process since the period of 1989-1991.

Rural areas in Ukraine cover $90 \%$ of the country's territory with the share of rural population ranging from $50 \%$ in western regions to less than $20 \%$ in the eastern parts (Prytula et al. 2014, p. 83). Ukraine is the second largest country in Europe with 43 million inhabitants, and currently classified as the poorest country in Europe. The conflict in the east of the country and relations with Russia have a negative impact on the economy, which is largely dependent on international aid. Ukraine is facing many challenges including the implementation of structural and institutional reforms, elimination of the effects of extensive development and ineffective resource management, the provision of tools and mechanisms supporting sustainability, and mitigation of the social effects of economic transition.

The choice of rural areas as the subject of research is justified, firstly, by the high percentage of the rural population in Ukraine; secondly, by the importance of reducing development disparities between rural and urban areas both in terms of access and competency gaps. For almost two decades across Europe, building the foundations of the information society in rural areas has been defined in terms of policy making-fair distribution of development opportunities has become a subject of constant concern for the European Commission and individual member states (Kaleta 2016, p. 155) and associated countries. Ukraine, as a country aspiring to become an EU member, has already adopted many solutions concerning reduction of development inequalities. A thriving creative and IT sector in Ukraine has become a significant sphere of the national export structure; accordingly, knowledge transfer should be prioritized to prevent rural areas from lagging behind. Overcoming disparities between rural and urban areas is crucial from the sociological perspective as a factor inhibiting migration from the countryside and, subsequently, depopulation of the rural areas. Rural areas and communities still struggle with the consequences of the socio-economic transition process-unfavorable demographic situation (Moroz 2010; Prytula et al. 2014), lack of employment possibilities (Moroz 2010; Moroz 2015), and decline in living standards and infrastructure deterioration (Dema et al. 2019; Kirieieva and Kostyuchenko 2017). Besides the socio-economic context, the adaptation of rural communities to the changing conditions of economic and political life is hampered by spatial and social distance (Borodina and Rykovska 2020).

The objective of this paper is to discuss the infrastructural and social aspects of dissemination of ICT in rural areas in Ukraine in order to identify its current state and indicate prospects for future rural development. The condition of ICT dissemination in rural areas in Ukraine is analyzed by referring to a broad background of other posttransition countries, serving as a point of juxtaposition.

In general, availability of new information and communication technologiesparticularly the Internet-is a factor that nowadays differentiates rural areas, and other regions to a lesser extent, than before (Jaska 2015, p. 110). In the European Union, the digital distance between large and small settlement units is constantly getting smaller; however, the question of spread and use of ICT in rural areas has become more complex. Modern discourse on digital connectivity emphasizes not only the issue of accessibility but mostly focuses on different usage patterns and the actual adoption of digital technology (Salemink et al. 2017). Yet the infrastructural aspect of rural-urban digital inequalities is worth noting: even in developed economies, the territorial factor affects the level of con- 
nectivity (Philip and Williams 2019). Rural areas are more likely to be digitally excluded in comparison to urban ones in terms of insufficient infrastructure such as lack of fixed broadband, slow connections resulting in lower involvement in a digital society, or underserved rural premises (Philip and Williams 2019). An important factor influencing the development of ICT is the level of wealth of a given country (Janc and Czapniewski 2013). Estimations of the International Communication Union included in the annual report International Communication Union 2020 demonstrate that two regions are struggling with the biggest digital divide-Africa and the Commonwealth of Independent States (CIS), "where respectively 23 and $11 \%$ of the population have no access to a mobile broadband network". In the case of ICT dissemination in the CEE countries, available statistics show disparities between rural and urban areas occurring in the region (Akca et al. 2007; Janc and Czapniewski 2013).

Recognition of the causes of the digital gap between rural and urban areas in Ukraine includes several factors influencing dissemination and use of ICT among rural dwellers. The analysis is focused on infrastructural and social aspects, mostly inherited from the USRR, which slow down the process of ICT diffusion in rural areas in Ukraine. The paper makes a theoretical contribution with an applicable value.

\section{ICT and Rural Development-Literature Overview}

According to the UNESCO Institute for Statistics (UIS) Glossary, information and communication technologies are defined as a "Diverse set of technological tools and resources which use storage devices to transmit, store, create, share or exchange information. These technological tools and resources include computers, the Internet (websites, blogs and emails), live broadcasting technologies (radio, television and webcasting), recorded broadcasting technologies (podcasting, audio and video players and storage devices) and telephony (fixed or mobile, satellite, visio/video-conferencing, etc.)" (Uis.unesco.org). This definition addresses the broad sense of ICT. "The term information and communication technologies is often used as a synonym for information technologies (IT), although ICT is a more general term that emphasizes the role of unified technologies and the integration of telecommunications (phone lines and wireless connections), computers, middleware, software, storage and audiovisual systems that allow users to create and obtain access to information, and store, transmit and edit it. In other words, ICT consists of IT, as well as telecommunications, media broadcasts, all types of audio and video processing, transmission, and the network functions of management and monitoring" (Kuzior and Lobanova 2020, p. 6).

Development of ICT contributes to socio-economic development (Kitchin 2015), supports sources of income (Jorgenson 2005; Delponte et al. 2015; Kaleta 2016; Novak et al. 2020), changes employment patterns (Janc and Czapniewski 2013), expands capabilities to mobilize internal resources (Shah et al. 2001; Campbell and Kwak 2010), equalizes educational opportunities (Delgado García and Chalmeta 2016), increases the attractiveness of rural areas (Stratigea 2011; Bajer 2012; Jaska 2015), contributes to knowledge exchange, and stimulates business networks (Wojnicka-Sycz 2013; Kuzior and Lobanova 2020).

Contemporary economic performance goes far beyond hard skills or investment volume (Murdoch 2000); the use of modern information and communication technologies (ICT) together with the transfer of creativity and innovation, and the institutional aspect such as management policies and practices, are the features of intelligent space (Nam and Pardo 2011; Kuzior 2010; Fernandez-Portillo et al. 2019) or, broadly, smart territory. Smart or intelligent space is described from the perspective of the significant influence of information technologies on the overall functioning of particular territorial structures (Jopek 2019, p. 7). In turn, the concept of smart territory may refer to many different spatial contexts, including rural areas, and refers to the use of ICT instruments in order to improve, for example, performance in agriculture, environmental protection, waste management. etc. (Navío-Marco et al. 2020). The idea of smartness assumes more effective-i.e., more intelligent-use of resources (Kuzior and Sobotka 2019). Respectively, smart development 
in the context of rural areas means searching for ways to implement solutions addressing problems of the countryside such as depopulation of rural areas and challenges related to climate change (Guzal-Dec 2018, p. 33). The question of depopulation of rural areas as one of the most important problems affecting rural areas in Ukraine will be described further.

Despite the strong representation of the "smartness" concept applied to non-urban spaces in contemporary scientific discourse (Grimes 2003; Akca et al. 2007; Spoor 2011; Kitchin 2015; Navío-Marco et al. 2020), it is worth underlining that the threat of digital exclusion affects mainly rural inhabitants (Kaleta 2016). Industrial society has brought economic development but has not counteracted the historical inequalities in access to such resources as education, health care, culture, work and participation in power, which negatively affects the quality of life (Kaleta 2016). Nevertheless, in post-industrial society, development inequalities have not disappeared-with the development of information society, a new kind of inequality has emerged (van Dijk 2010; Dragulanescu 2002; Boje and Dragulanescu 2003; Spoor 2011; Kos-Łabedowicz 2017).

Differences in access to new media due to structural inequalities are defined as the digital divide (van Dijk 2010). Information and communication technologies are one of the essential future technologies that can be employed in every sector of the economy, but despite the unquestionable boost in ICT, rural areas still remain a challenge in terms of their spread (Akca et al. 2007). As noted by Grimes, "peripheral rural areas by nature have always suffered from serious infrastructure disadvantages" (Grimes 2003, p. 175) and the gap in living standards between rural and urban population is remarkable (Meijere and Tambovceva 2017). Digital inequalities resulting from geographic factors, correlated with education level and unemployment rate, were analyzed, for example, by Park (2017). According to the International Communication Union report Measuring digital development: Facts and Figures (International Communication Union 2020), in developing countries access to the Internet in rural areas was 2.3 times lower in comparison to urban areas. The dominant discourse concerning rural areas still remains far from the issues of smart development. The social construct of the countryside includes clichés of peripherality, conservatism and backwardness (Shuldiner 2020), underserved or economically disadvantaged areas (Akca et al. 2007), "forgotten" places without access to culture (Rakowski 2016), or countryside idyll as opposed to technology (Cowie et al. 2020). Countryside and rural areas cannot remain discounted from both the worldwide and nationwide discussions on smart development- "Without making the village smarter, the nation cannot grow and be progressive" (Fajrillah et al. 2018, p. 5).

Analyzing the problems of rural areas within the framework of intelligent development is associated with a broad economic, social and cultural context. A literature overview allows us to enumerate the reasons for the noticeable decline in interest in rural areas as a research area. These include mostly demographic factors, such as the growing role of cities and predictions of an increase in the urban population (Action Program Agenda 21); and economic reasons-mainly a decrease in the importance of agriculture as a sector of the economy (Wójcik 2009). Yet, concerning the discussed issues, social aspects should also be taken into account. The degree and dynamics of change in rural areas is significantly different-as noted by Murdoch (2000): "rural issues have a life of its own. ( ... ) rural areas continue to follow their own stubborn logic ( . . )" (p. 407). One of the most common features of countryside dwellers is a higher level of conservatism and resistance to innovation (Kaleta 2016). As underlined by a number of scholars (Grimes 2003; Akca et al. 2007; Kitchin 2015; Yin et al. 2019; Cowie et al. 2020), the discourse of "smart technology as a solution to 21st century city problems acts to marginalize rural areas which do not suffer from these specific urban problems but instead face their own distinct challenges" (Cowie et al. 2020, p. 170). Among the consequences of unequal access to ICT, a lower involvement in important social areas should be noted. An interconnection between Internet use and civic engagement has been recognized: the Internet is used for informational purposes, for entertainment, but also for maintaining connections and establishing virtual communities - what contributes to the individual-level production of 
social capital (Shah et al. 2001). The positive role of mobile communication in civil society was highlighted for example by Campbell and Kwak (2010). In turn, access to ICT is indicated as an important factor in career development or running a private business (van Dijk 2010) - the role of ICT in this area can be defined in terms of a tool to explore and acquire information or technical solutions reshaping the concept of work.

According to sociologists, farmers' households are most at risk of structural exclusion including digital and informational exclusion, related to low level of education and place of residence (Guzal-Dec 2018). Access to the whole range of opportunities offered by the Internet is not only the ability to connect to the network: structural factors such as age, economic status, education or social capital have significant impact on difference in Internet use between the rural and urban population (Janc and Czapiewski 2014). In order to prevent digital and information exclusion, the information needs of the recipients, as well as the ability to obtain, use and combine different kinds of information, should be recognized (Jaska 2015). Disparities in access to ICT between rural and urban territories are constantly decreasing; however, the level of awareness of the role that ICT plays in economic growth and development among rural inhabitants in not sufficient. Thus, activities encouraging continuous education in this field are strongly recommended-both for individuals and social groups (Janc and Czapiewski 2014; Jaska 2015; Kaleta 2016).

Possibilities arising from ICT require not only physical possession of the device; van Dijk has already distinguished four different dimensions of access to digital technology: (1) motivational; (2) material-based; (3) competence-based; (4) utilitarian (van Dijk 2010). In the case of rural dwellers competence-based access seems to be of great importance. As noted by Kaleta (2016): "lower readiness to accept modern technological solutions, including new work, study or other types of life activities could appear in the countryside in terms of ICT dissemination" (p. 39). Competency access consists of the following skills: operational (ability to use hardware and software), informational (ability to search, select and process the obtained information) and strategic (ability to use ICT in order to achieve personal goals or improve social position) (van Dijk 2010).

Rural areas, if they develop in the smart direction, can become smarter than cities, Shuldiner (2020) claims. Intelligent development in the context of EU rural areas means "searching for ways to implement the concept of sustainable development regarding the problems of rural development, in particular peripheral areas (such as depopulation of rural areas and outflow of youth) and challenges related to climate change" (Guzal-Dec 2018, p. 33). The vision of a smart village appeared almost at the same time at the level of academic debate and in the process of policy making at EU level-the main source is the Cork 2.0 declaration of 2016 (Visvizi et al. 2019). The concept of the smart village is associated with the value of digital technologies, knowledge and innovations affecting the improvement of the quality of life, better use of resources, support for entrepreneurship, or offering benefits of natural environment protection. The idea of the smart village does not provide a universal solution - it is a regionally sensitive approach, based on deep analysis of the needs and development strategies of the region, supported by new or existing territorial strategies (Fajrillah et al. 2018). Local and regional development is defined by the features of the specific place-cultural specificity, natural conditions, social organization, diversity, resilience or susceptibility to external factors (Wójcik 2018, pp. 6-7). Therefore, overcoming social inequalities and development barriers (Kuzior 2010), or increasing social involvement at the local level requires the establishment of development opportunities based on local resources and supported by ICT (Fernandez-Portillo et al. 2019).

\section{Materials and Methods}

To achieve the objectives of this paper, the method of content analysis was mainly employed. The source material is based on already existing data, which consists of selected literature on the subject of rural development in the EU and beyond, strategic documents, available reports and studies of international institutions, work from research agencies, state documents and statistics, and research conducted by international and domestic 
NGOs. The information sources of the data being researched in order to compare indicators for Ukraine with such countries as Poland or the Slovak Republic included World Bank data, Statistics Poland Service, and Eurostat database.

The course of study represents the nomothetic approach in social and management sciences (Dzwigoł and Dzwigoł-Barosz 2018) with the focus on the framework of economic, infrastructural, and social factors affecting rural development in Ukraine since the postcommunist transition period.

The sections are as follows:

Firstly, an analysis of the scientific literature was used in order to define the concept of ICT and its contribution to rural development. In the literature overview we looked at the terms smart space, smart territory, smart development, and structural inequalities in the access to resources including ICT.

In the second step, economic and social factors of rural development in Ukraine were identified, with regard to the perspective of transition studies. Rural issues in Ukraine were briefly described in reference to the other countries of Central and Eastern Europe. Ukraine-as a lower-middle income country-was contrasted with the other countries of the region, such as Russia and those within the European Union (Poland, Czech Republic, Slovak Republic) and other former USSR countries like Kazakhstan (in order to show the divide between the CIS and the other post-communist countries).

The arguments in favor of such a juxtaposition are as follows: (1) the comparison with countries starting transition in 1989-1991 and already belonging to the EU outlines European priorities in the sphere of research and development ( $\& D)$ and serves as indicator of progress in this area; (2) on the other hand, the Russian Federation as the heir of the USSR is important as a point of reference for the post-soviet countries. Comparing different lower-middle income countries enables us to reveal the performance of Ukraine in the sphere of technology upgrading. The next step of the study involved recognizing challenges in ICT diffusion in rural areas, highlighting the infrastructural and social aspects, and referring to the available data on horizontal divisions (the urban-rural digital divide).

The keystones of analysis involved (1) outline of the area of research; (2) selection of literature; (3) collection of available data and indicators relevant for comparison of chosen rural issues in Ukraine and CEE countries; (4) description of key determinants for ICT dissemination in Ukraine; (5) justification and conclusion.

\section{Research Results}

\subsection{Socio-Economic Factors in Rural Areas' Development in Ukraine}

During the post-communist transition period taking place from the 1990s, rural areas have been at high risk of exclusion from the benefits of the socio-economic shift (Spoor 2011; GFK Hungary 2015) and rural dwellers have often escaped in resentment (Buchowski 2004). The new reality for many social groups was associated with loss of status, pauperization, and degradation. A Polish sociologist characterized this phenomenon as a "trauma of a great social change", i.e., an experience disorganizing previous social life and initiating new patterns of behavior (Sztompka 2000, 2004). The symbolic end of the post-communist transition period for the countries of Central and Eastern Europe is determined by accession to the EU. However, other countries of the region-including Ukraine have remained at this stage (Magosci 2017, p. 929).

Rural areas in Ukraine are still struggling with the post-socialist inheritance such as: lack of work, labor migration to the cities, depopulation, loss of morale (Keyzar et al. 2013; Dema et al. 2019; Kirieieva and Kostyuchenko 2017). Since 1991, Ukrainian agriculture has been exposed to serious upheaval, including the loss of traditional markets, deterioration of trade conditions, and limited access to international loans (von Cramon-Taubadel and Zorya 2001; Sarna 2014). Social infrastructure as well as housing conditions in many rural settlements in Ukraine have been neglected: rural inhabitants do not often have access to health facilities, kindergartens, cultural activities; rural housing often lack running water, appropriate heating and sewer lines (Skryzhevska and Karacsony 2012; McKee et al. 
2006). In Soviet times, about 12,000 state farms operated in Ukraine on over 35 million hectares of land. Individual farms appeared in Ukraine as a result of the law adopted in 1993, under which the collective state farm assets were privatized. State farms provided not only employment, but supplied local communities with social facilities, organized transport, housing and even cultural life (Keyzar et al. 2013). The other side of the rapid industrialization and urbanization in the Soviet Union was underinvestment in the housing sector- "In rural areas that had historically been disadvantaged the situation was even worse, as many of them still had extremely limited access to water when the Soviet Union broke apart in 1991" (Roberts et al. 2012, p. 353). In 2004 82\% of rural areas had no access to a public water pipeline, $98 \%$ were deprived of a sewage system, and $85 \%$ were not connected to a gas pipeline (Pantyley 2009, p. 50). The contemporary divide in quality of housing and infrastructure between suburban and rural areas is still not covered"only $31.5 \%$ of the rural housing stock is connected to centralized water supply systems" (Kirieieva and Kostyuchenko 2017, p. 124). According to the Ministry of Agrarian Policy and Food of Ukraine (2015), the poverty rate in rural areas is 1.7 times higher than in urban areas and, in terms of living conditions, the percentage of poor rural and urban households is respectively 39\% and 19\% (Single and Comprehensive Strategy and Action Plan for Agriculture and Rural Development in Ukraine for 2015-2020).

Higher rural poverty figures and drawbacks in access to social services apply to other transition countries-according to the Transition Report 2007: People in Transition (European Bank for Reconstruction and Development 2007), in 2006 piped tap water was available for only 12.9\% rural dwellers in Kazakhstan, 16.8\% in Moldova and 33.8\% in Kyrgyzstan (Spoor et al. 2014, p. 2006). In Ukraine, access to public piped tap water in rural areas reached $43.8 \%$ in 2006 and 53\% in 2010 (Spoor et al. 2014, p. 2006). Insufficient infrastructure still remains a challenge in the countries of the former Soviet Union, especially in Central Asia (Spoor 2018) - for example, as far as water supply is concerned, in Kazakhstan only $28 \%$ of rural inhabitants have access to piped water (Tussupova et al. 2016). In comparison, in Poland disparities in water supply between rural and urban areas have decreased significantly $-71 \%$ of the rural population in Poland had access to public piped tap water in 2004 and 72.5\% in 2006 (Berkowska et al. 2010, p. 189). According to Statistics Poland, in 2016 there were 173 communities with percentage of flats connected to the water supply below $80 \%$, including two local units with a share of less than $50 \%$ (Komorowski and Monika 2019, p. 785). The Polish countryside is getting better equipped with water and sewage infrastructure; however, there are still disproportions between rural and urban areas in terms of technical infrastructure, especially sewage system (Berkowska et al. 2010, p. 188).

In Ukraine, poor housing conditions and insufficient level of communal infrastructure are indicated as one of the drivers of out-migration: "the larger the city, the better its infrastructure is" (Nefedova et al. 2016, p. 136). The change of the migration vector in favor of the countryside was observed at the beginning of the socio-economic transformation (1991-1993). It was related to the decrease in living standards and the inability to obtain a free dwelling in the city, yet data collected in the period 1993-1996 shows a ten-fold increase of movement from the village to the city (Pantyley 2009, p. 47).

Regarding rural and semirural areas in Ukraine, the main development barriers result from the decrease in production and, as a consequence, the reduction in the number of workplaces, which was most noticeable in areas where one production branch dominated. One of the unwanted effects of these processes was the rise of unemployment, and the other a lack of revenues in the budgets of local governments, which affected the deterioration and even degradation of social and road infrastructure (Synowiec 2018). High unemployment rates affected rural areas in Ukraine in the period 1997-2003 and as a result the share of informal labor has increased, particularly in agricultural activities (Moroz 2015; Chreneková et al. 2016). Domestic researchers dealing with the issue of the forming of a middle class in Ukraine indicate that almost one third of the country's population belongs to the lower class-these are mainly inhabitants of rural areas in the western oblasts 
(Razumkov Center 2014). The standard of living of rural dwellers tended to gradually decline if compared with the average level in the country (Moroz 2010).

A noticeable change in migration patterns is also worth mentioning. Commuting between small settlements and cities for education or work purposes is gradually being replaced by permanent migration, and thus the concentration of population in cities and district centers (Sustainable Development Goals: Ukraine 2017, p. 85). “Employment is also associated with the size of cities. Analysis ( ... ) shows that the average salary decreases with decreasing city size, while the proportion of unemployed working-age population increases" (Nefedova et al. 2016, p. 135). As a result, the countryside was affected by the process of depopulation (Pantyley 2009). The number of rural residents fell by 1.7 million from 2001 to 2013 (Single and Comprehensive Strategy and Action Plan for Agriculture and Rural Development in Ukraine for 2015-2020).

The rural-urban gap in equal access to social services in Ukraine remains noticeable. According to official estimations, "most rural residents do not have access to high quality healthcare or educational services. As little as 26 percent of rural children attend kindergartens. Graduates of rural secondary schools have much worse results in external independent tests than their urban counterparts" (Single and Comprehensive Strategy and Action Plan for Agriculture and Rural Development in Ukraine for 2015-2020).

However, in the CEE countries there is still a remarkable percentage of rural population in relation to urban residents. The actual share of the rural population ( $\%$ of total population) in Ukraine is $31 \%$, while in Poland the rate is $40 \%$ and in Slovak Republic this indicator reaches $46 \%$ (World Bank Indicators 2018). In some areas, quality of life prospects make rural areas an increasingly attractive and desirable place to live. For example, in Poland, there is a decrease in the urban population in favor of the countryside-in 2015, the share of the rural population in the total population was close to $40 \%$, reaching its highest level since the socio-economic transition in 1989 (Statistics Poland 2017). However, the dynamics of the downshifting process (the tendency to move backward from cities to countryside) relates not only to remote rural areas but also to suburban areas that are defined as rural only due to the conventional description. In the case of Ukraine, the phenomenon of downshifting is not relevant due to the current economic situation (Maksymenko and Roman 2015) - "the tendency for the young active part of the rural population to move to cities has strengthened" (Kuczabski and Michalski 2013, p. 83). Furthermore, one of the long-term consequences of the transition process in Ukraine is depopulation of rural areas. According to the estimations, the rural population of Ukraine reduced by 147,000 people every year; the number of villages also decreases: for the period from 1990 to 2017, 468 villages disappeared from the map of Ukraine, i.e., an average of 18 villages annually (Agroportal.ua 2018).

As far as the economic sources of livelihood in the countryside are concerned, $28 \%$ of rural inhabitants in Ukraine indicated agriculture as the main income opportunity-as reported in a nationwide survey conducted in 2013 (Gorshenin Institute 2013; Moroz 2015). In turn, in Poland agriculture remains the main source of income for about $10 \%$ of the rural inhabitants (Wilkin and Nurzyńska 2018). The share of women and men employed in agriculture in Ukraine in comparison to other countries of the region is presented in Figure 1. The relatively high rate of Ukrainians working in agriculture indicates the important position of this industry in the structure of the national economy. 


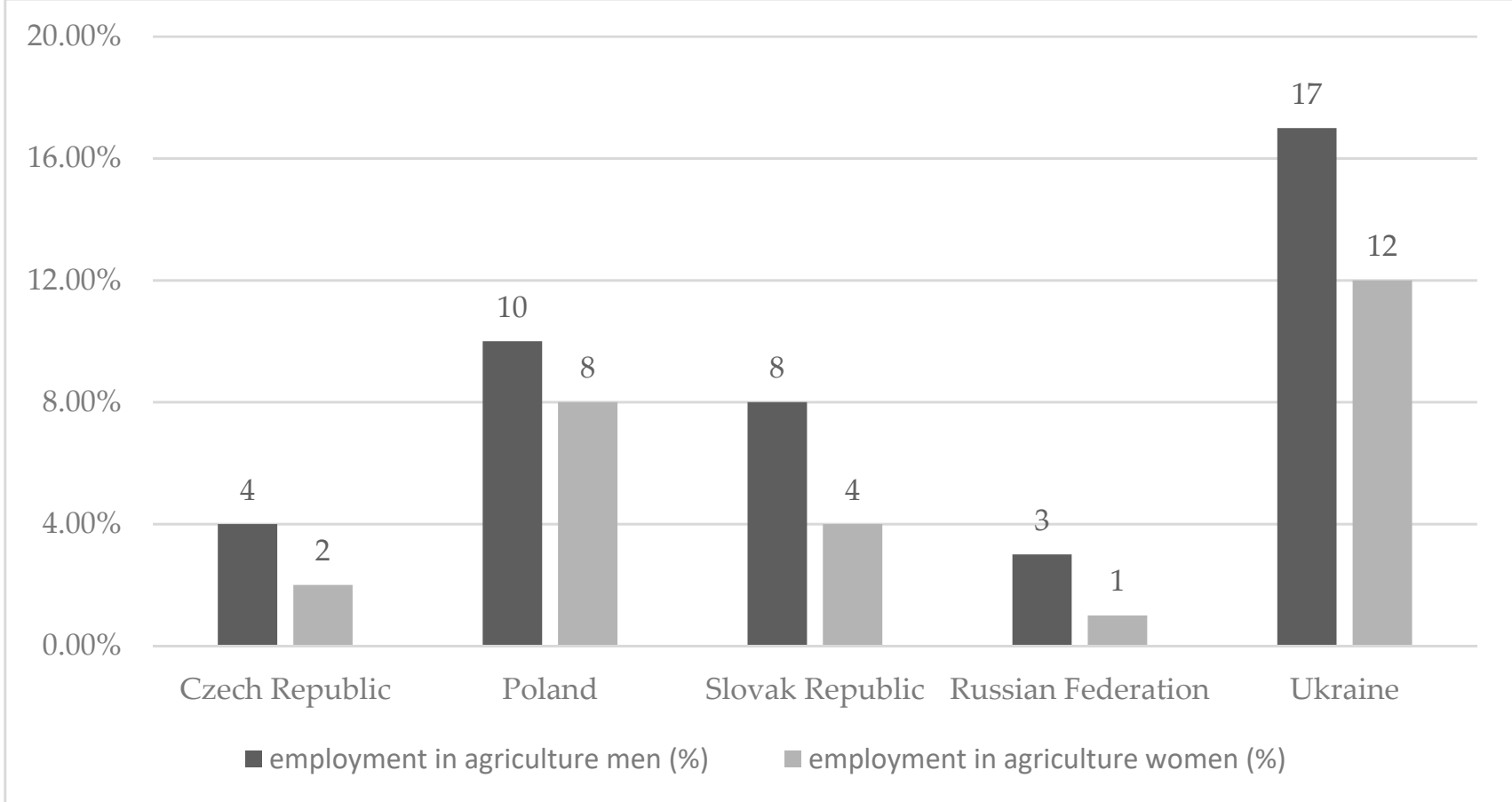

Figure 1. Employment in agriculture, male (\% of male employment) and female (\% of female employment) in chosen Central and Eastern European countries in 2019. Source: developed by author based on World Bank Indicators https: / / data.worldbank.org/indicator/SL.AGR.EMPL.MA.ZS?locations=UA-CZ-RU-PL-SK.

The trend showing the decline in the share of agriculture in the GDP structure and the increase in economic activity in other sectors seems to illustrate the gradual transition of the economy and society-economic performance in rural areas is developing towards services (Kaleta 2016). In Poland in 2016, more than every fourth entity registered in the National Official Business Register was located in rural areas; $44 \%$ of the employed was working in industry and construction, $21.9 \%$ in trade, transportation and storage, accommodation and catering, information and communication, while almost $28 \%$ worked in other services (Statistics Poland 2016). An important factor influencing the socio-cultural space of the countryside is rural tourism, including various forms of recreation in the countryside and the choice of green tourism locations as a lodging base (Roman and Niedziółka 2017, p. 14). The development of tourism creates favorable conditions for undertaking other types of economic activity in rural areas (Pałka-Łebek 2017).

However, in Ukraine the structure of income sources in rural areas shows the still strong position of agriculture compared to other economic activities (Moroz 2015). The structure of income sources in rural areas in Ukraine in 2013 is presented in Figure 2: 


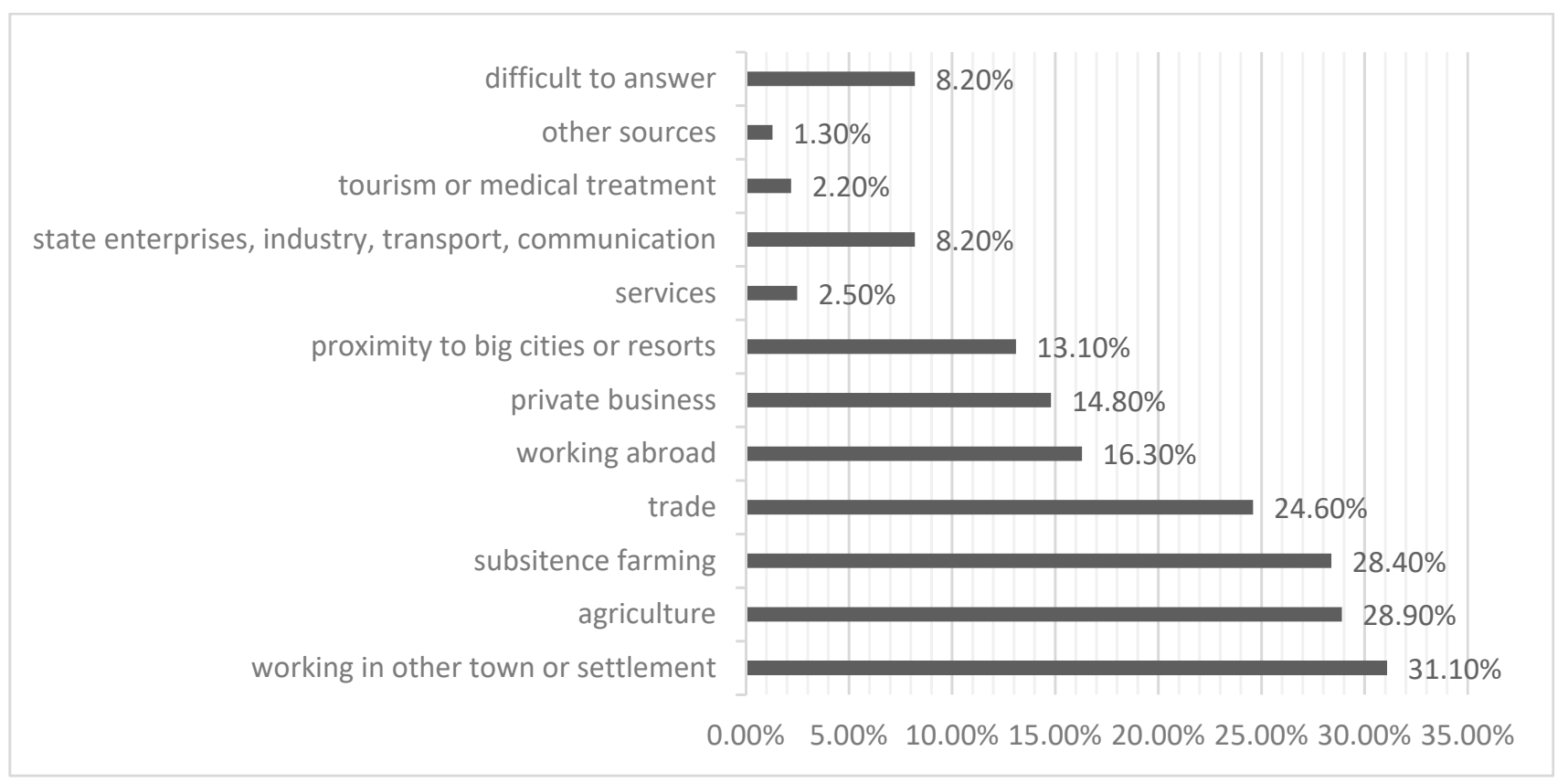

Figure 2. Structure of income in rural areas in Ukraine in 2013 (Note: respondents could select up to three answer options). Source: (Gorshenin Institute 2013; Moroz 2015).

\subsection{Telecommunication Development in Ukraine-An Overwiev}

The issue of telecommunication infrastructure in rural areas in Ukraine remains insufficiently explored (Riznyk 2016); however, works on the history of telephone communication development during the Russian Empire and Soviet Union also cover the Ukrainian landsfor example, Shlyakhov (2018) analyzes the beginnings of telephone communication in the Ukrainian lands of the Russian Empire, Riznyk deals with the structure and organization of rural post offices at the turn of the 19th and 20th centuries (2016) and indicates other domestic researchers who focus on the development of postal services in different provinces in the late 19th-early 20th century (Riznyk 2016). The first regulations regarding telephone networks were launched in the Russian Empire in 1881. Shortly after, five major royal cities were provided with the construction and operation of telephone networks; Odesa was one of them (Shlyakhov 2018, p. 53). In 1900 the number of government telephone network subscribers in Ukrainian provinces of the Russian Empire was above 4000 (Shlyakhov 2018, p. 54). Upon the 1919 decree On the Nationalization of Telephone Communications of the Russian Republic all public telephone networks located in the territory of the Russian Socialist Federal Soviet Republic, with all assets and belongings, became the property of the Russian Socialist Federal Soviet Republic (Solnick 1991). In the Soviet era, "the development of electrical communication technologies was a concomitant of literacy acquisition. ( . . ) some technical devices, such as telephone, appeared to remain bound to the urban context of communication: for most of the Soviet times, telephone was mainly used in the cities by literate subscribers" (Zakharova 2016, p. 183). Institutional use was prioritized in Soviet Union-only 17.1 million network telephones in 1989 were residential $(55 \%)$, while at the same time in USA more than $80 \%$ belonged to residential subscribers (Campbell 1988, p. 15). Although the People's Commissar of Posts and Telegraphs Vadim Podbelsky claimed to provide every worker and every peasant with access to mail, telegraph and telephone as benefits of modern culture, this was never achieved (Pravo.ru 2015). Requirements for establishing a modern communication system were evoked in the Eleventh Five-Year Plan (1981-1985): “The number of telephones connected to rural exchanges was to be increased by $43 \%$ and to urban exchanges by $33 \%$. A large share of new installations was to go to households" (Campbell 2019). The limitations of the Soviet 
telecommunications system such as the lack of capacity to meet the needs of contemporary society and inadequate technical standards were underlined by Campbell (1988). One of the indicators illustrating the technological backwardness of the Soviet telecommunications system is telephone density in USRR at the end of 1985. In the mid-1980s, the average number of telephones per 1000 inhabitants in the Russian Soviet Federative Socialist Republic (RSFSR) was 122 and 114 in Ukraine-while in relation to the rural areas there were only 64 telephones in the Russian and 44 in the Ukrainian Soviet Republic (Campbell 2019). Campbell also drew attention to the problem of the concentration of telecommunications networks, with a distinct advantage of the RSFSR over the other fraternal republics: at that time Moscow with 3\% of the country's population had 11\% of all the telephones provided (Campbell 1988, p. 16). On the other hand, a poor quality telecommunication network was a problem not only for the USSR, but also for other countries in the region: at the same time density of telephones in Poland reached an average of 109, 140 in Hungary, and 226 in Czechoslovakia; in rural areas density of telephones was estimated as one-fifth of that in the cities (US International Trade Commission 1991, p. 26). Both in the case of the USSR and other CEE countries, a telephone installation in the household involved joining the waiting list (Campbell 1988).

The telecommunications infrastructure inherited by independent Ukraine was recognized as underdeveloped-in 1994 telephone density in Ukraine was only 18 out of 100 inhabitants (Prozhivalsky 1994, p. 42). In order to develop Ukraine's telecommunication sector in line with modern standards, the National Telecommunication Development Program was introduced (Prozhivalsky 1994, p. 42). The Internet firstly appeared in Ukraine in 1990; in 2010 the State Committee for Communications recorded more than 15 million individual users, a third of the total population of Ukraine (Dubov et al. 2010). Since the emergence of the Internet in Ukraine, the digital industry has been constantly growing, with information technology as one of the most dynamic business sectors. "The estimated number of IT companies in Ukraine varies considerably depending on the data source. According to official data, there were 12,634 companies as of the end of the first half of 2018 ( . . ) According to unofficial data, in Ukraine, there are about 4 thousand companies" (IT Ukraine Association and The Better Regulation Delivery Office 2018, p. 5). Official estimations show that half of the entities operating in IT are registered in Kyiv. The Ukrainian information technology industry has become an important branch in the structure of national exports, with computer services in third position in export items, reported in 2017 (IT Ukraine Association and The Better Regulation Delivery Office 2018).

Mobile telecommunication systems and Internet are developing rapidly in Ukraine; however, there are still disparities between access to ICT in Eastern and Western Europe (especially Nordic countries). Ukraine has the lowest level of broadband subscribers per 100 people and achieved the smallest increase in new subscriptions (World Bank Group 2019). The share of the individual Internet users (\% of population) in Ukraine in 2018 was 62.5\%, 77.5\% in Poland, 80.1\% in Czech Republic, 80.4\% in Slovak Republic, and 80.8\% in Russian Federation (World Bank Indicators 2018). Respectively, in the same year the share of individual Internet users reached 93\% in Denmark and Sweden, 94\% in Finland, 98\% in Netherlands and 99\% in Iceland (Statista.com). Regarding ICT expansion in CEE countries-now UE member countries-it has not been progressing evenly. While Estonia, Slovenia, and Latvia maintain leader positions, Poland, Slovakia, Bulgaria and Romania are the countries with the largest percentage of population digitally excluded (Ziemba and Becker 2019, p. 1). The dynamics of growth of individual Internet users in Ukraine and chosen CEE countries in the period 2000-2020 is presented in Figure 3. 


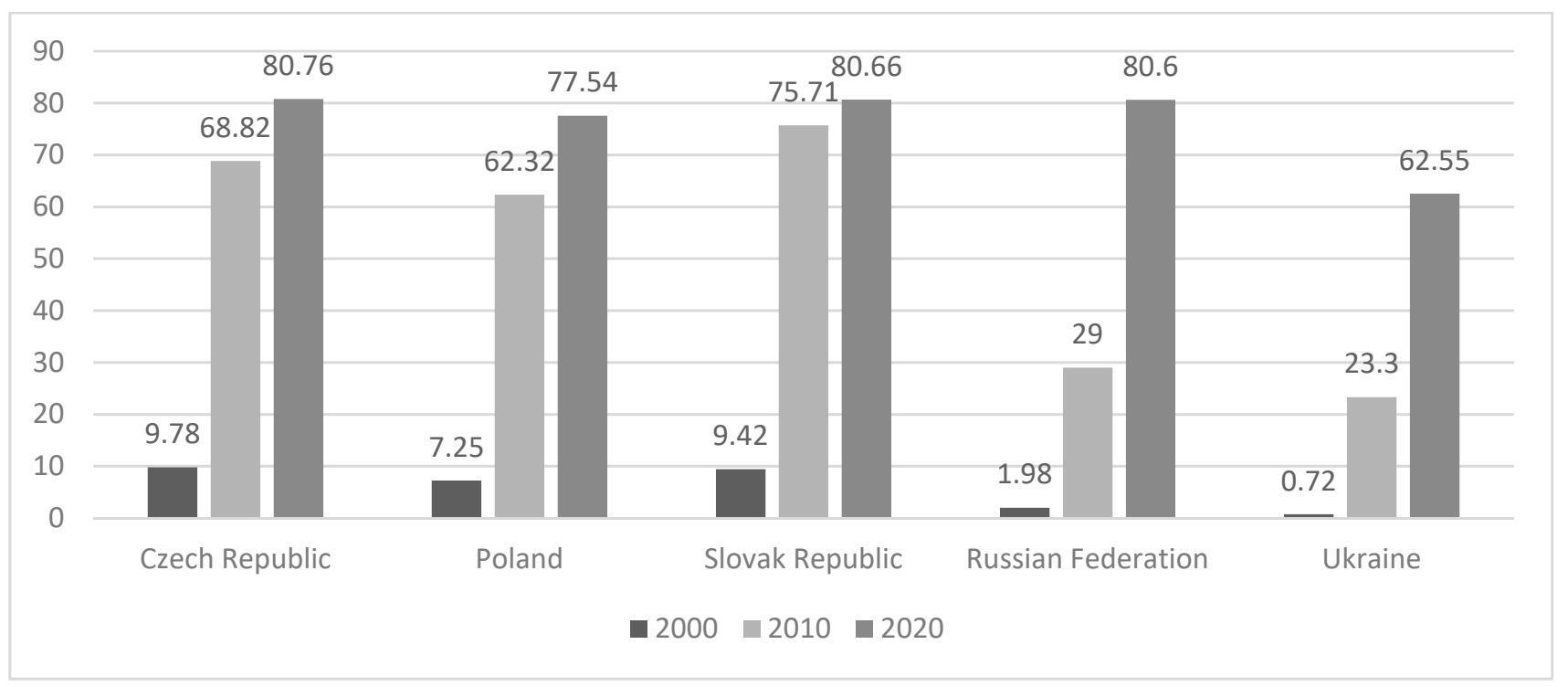

Figure 3. Share of individuals using the Internet (\% of population) in chosen Central and Eastern European countries in 2000-2020. Source: developed by author based on World Bank Indicators 2018 (https:/ / data.worldbank.org/indicator/IT. NET.USER.ZS?locations=CZ-PL-RU-SK-UA).

\subsection{Access to ICT in Rural Areas in Ukraine - Infrastructural Dimension}

As far as Central and Eastern European countries are concerned, the question of a "digital divide" could be addressed from three aspects: (1) the divide between the most industrialized countries in the world (so-called West-East Digital Divide); (2) between different countries of the region (the so-called East-East Digital Divide); (3) between different social groups within the societies (Dragulanescu 2002; Boje and Dragulanescu 2003). Access to the Internet in rural areas is associated with higher costs of infrastructure development-lower population density and inferior access to resources such as the labor market or information (Janc and Czapiewski 2014; Kaleta 2016). ICT, as one of the essential future technologies, can be employed in every sector of the economy-therefore the reduction or eradication the digital divide between rural and urban areas is unquestionably a requirement for intelligent development.

For example, in Poland equipping rural households with a computer with Internet access in 2015 increased by 38 times in comparison to data collected in 2000-from 1.8\% to $68.5 \%$ (Statistics Poland 2017). In Ukraine, though, the situation with the nationwide network accessibility remains different. According to Global Digital 2018-a suite of reports across 239 countries released by the international agency We Are Social, specializing in media research -25.59 million Ukrainians are Internet users, which means $58 \%$ of the total population (Global Digital 2018). "The problem of digital divide in rural areas is determined by factors different than in the case of urban areas and can affect both the supply and the demand side in terms of physical access to the Internet" (Kos-Łabędowicz 2017, p. 200).

Most of the available statistics on access to information and communication technologies indicate disparities between rural areas and cities. According to the research conducted by the largest provider Ukrtelekom, in Ukraine 21.7 thousand villages are left without the Internet; in cities with a total number of 26 million inhabitants, almost 98\% can easily connect with the network (Liga.biznes 2018). An updated nationwide study prepared by the same contributor in order to identify and reduce the digital divide shows there are about 6.3 million people living in Ukraine (15\% of the total population) who are not covered by the networks of any Internet service operator (Ukrtelekom.ua 2019). The limitation of the telecommunications infrastructure in some localities (problems with access to broadband Internet in particular) is considered the determining factor for 
the emergence of digital inequalities in Ukraine. According to official data, the level of broadband Internet penetration in Ukraine is only 11.8 subscribers per 100 inhabitants (in neighboring Slovakia-23.3; in Hungary-27.4; and in Belarus-31.4) (Myskevych 2019). As pointed out by Myskevych (2019), the access to broadband Internet differs remarkably along with the place of residence in favor of big cities: $28 \%$ of all broadband subscribers live in Kyiv, while the rest of the country (except Kyiv, Dnipropetrovsk, Donetsk, Odesa, Lviv and Kharkiv oblasts) accounts for only $40 \%$ of the total share of subscribers. At the same time, Ukrtelekom has stated that the average monthly use of gigabytes does not differ exceptionally due to the place of residence: "subscribers living in cities consume around of 194 gigabytes monthly, while residents of small settlements use 165 gigabytes" (Myskevych 2019). One more important factor should also be taken into account-connecting rural households to the Internet is more expensive if compared to urban ones; in rural areas people may also face the problem of fewer opportunities of choice of provider. However, patterns of the Internet consumption among urban and rural populations tend to be similar: rural residents use social networks, service platforms and make online payments, so the problem is not a lack of need, but a lack of opportunity (Myskevych 2019).

The size of the digital gap between the city and the countryside in Ukraine is decreasing. This was reported by the press service of the Internet Association of Ukraine with reference to the results of a study by Factum Group Ukraine 2019. Thus, the total share of Internet users in villages increased from $45 \%$ in 2015 to about $58 \%$ at the end of 2019 . The situation in cities with a population of up to 100,000 has also improved from $62 \%$ in 2015 to $70 \%$ in 2019. The Internet coverage in the Ukrainian countryside has reached 53\% (Factum Group Ukraine 2019). The differences between Poland and Ukraine in Internet access in rural areas are shown in Figure 4.

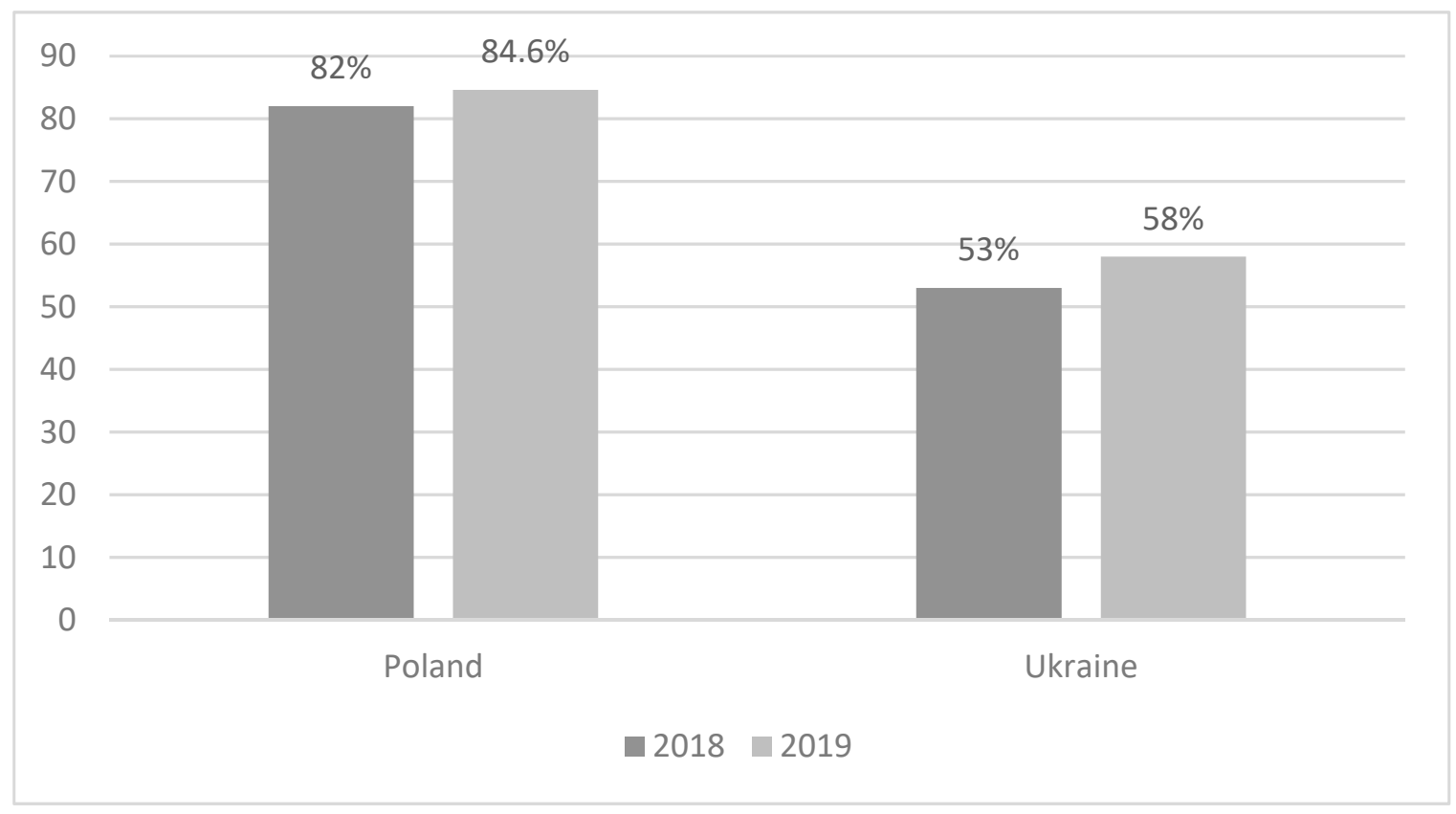

Figure 4. Internet accessibility in rural areas in Poland and Ukraine in 2018-2019 (\% of population). Source: developed by author based on Factum Group "Internet coverage in Ukraine III quarter of 2019"; Statistics Poland 2019.

Regarding the use of technology in Ukraine, it is also worth paying attention to other dimensions like the evolution of $\mathrm{R} \& \mathrm{D}$ activities. The engagement in innovative activities is estimated to be lower than in peer countries- "innovative activities are concentrated in the three largest urban areas. The top three innovative regions, which are Kyiv, Harkiv, and Zaporozhie, account for $48 \%$ of innovation expenditure and $56 \%$ of innovative activity" (World Bank Group 2019, p. 15). The above estimates show, firstly, the differences between 
regions, and secondly they define the domain of innovation as so far related only to large urban centers. In order to upgrade the performance in innovative activities and in the R \& $\mathrm{D}$ area, Ukraine needs to further its capacities in technology absorption. This means, for example, to develop infrastructural and organizational factors for access to technology, to increase the level of managerial capabilities in the sector of small and medium enterprises, to support engineering education programs and counteract brain drain processes related to out-migration, and to improve interconnections with the global economy (World Bank Group 2019).

The emergence of ICT as a factor of productivity growth can affect the competitiveness of states (Kos-Łabedowicz 2017). According to World Bank experts, in general “Ukraine fairs poorly in terms of technology upgrading. Ukraine ranks last among comparison countries in a composite index of technology upgrading, with especially low performance in terms of production, management, and R\&D capabilities. Ukraine scores somewhat better in terms of structural features, though it still ranks poorly due to weak organizational capabilities" (World Bank Group 2019, p. 2). In September 2014, the Council of Europe and the European Union allocated $€ 2.75$ million to Ukraine for a project aimed at strengthening the information society in Ukraine-one of the objectives was ensuring greater freedom of the media and an open, citizen-centered approach to the Internet.

As claimed in the memorandum signed between the Cabinet of Ministers of Ukraine and the largest mobile and telecommunications operators in Ukraine, by 2022, 90\% of Ukraine's settlements should have access to 4G Internet (Hromadske.ua 2019). In May 2019, a decree launching 5G technology in Ukraine was signed by the president-under this decree a plan for implementing 5G technology will be developed and adopted (National Commission for the State Regulation of Communication and Informatization n.d.). However, if the speed of connection is considered in relation to rural areas, providing high-quality Internet to thousands of villages is an expensive operation given the market realities, and, therefore, at this stage of development $3 \mathrm{G}$ and $4 \mathrm{G}$ are a great solution only for megacities (Myskevych 2019).

\subsection{ICT in Rural Areas: Social Aspects}

The Internet "as an exact technical notion is a form of access to the deposits of abundant stores of data from all over the world independent of their location in space, and also it enables communication" (Janc and Czapniewski 2013, p. 90). Internet access is defined as the process of connecting individual users or organizations to the Internet by means of devices such as personal computers, laptops or mobile devices, characterized by different speeds of connection.

Referring to data on Internet density in Ukraine, it is worth underlining that almost $15 \%$ of the total population is not covered by any network (Ukrtelekom.ua 2019). More than 21,000 villages have no access to the Internet-this means many rural dwellers cannot approach modern opportunities for education or e-commerce. Yet the infrastructural dimension is not the only one accountable for the digital divide. Digital skills and affordability of Internet services also relate to digital inequalities. Digital competence refers to the various aspects and contexts of information technology use, including "selecting, storing, processing and exchange of information, with a particular focus on specificity of the interactive media. This competence requires knowledge of computer literacy and available applications as well as other IST tools, and also critical assessment of the Internet resources" (Kuzior 2014, p. 73).

The problem with Internet access has proven to be particularly severe in connection with the organization of nationwide distance learning due to the COVID 19 pandemic. According to a study conducted by the Pro.Svit organization, about $1 \%$ of Ukrainian teachers do not have internet at home, and another $5.5 \%$ can only use mobile Internet, which does not always ensure stable connection quality (Pro.Svit 2020). The 4G mobile Internet standard would help solve these communication problems; still there are almost 6000 settlements in the country where there is no connection. The negative phenomenon of 
impaired digital literacy that occurred due to the COVID-19 pandemic was identified as one of the triggers hindering development (UNDP Ukraine 2020).

In this context, the first nationwide Report on digital literacy of the population of Ukraine (Ministry of Digital Infrastructure of Ukraine 2019) is worth referring to, as it shows that $53 \%$ of Ukrainians are below the average mark according to the digital skills assessment methodology used by the European Commission (Ministry of Digital Infrastructure of Ukraine 2019). As far as rural areas are concerned, almost $60 \%$ of interviewees declare their level of digital skills as "low" or "no skills". The same study discovers that connection to the Internet for the vast majority of Ukrainians is provided by mobile phone: telephone is the main device used to access the Internet for $93.4 \%$ of youth (age 18-29), for $85 \%$ of people aged $30-59$ and for $64.5 \%$ in the group $60-70$ years old. As far as the indicators of financial inclusion are concerned, here Ukraine has lower rates mainly in the aspects of having a bank account and making payments or purchases online (Figure 5).

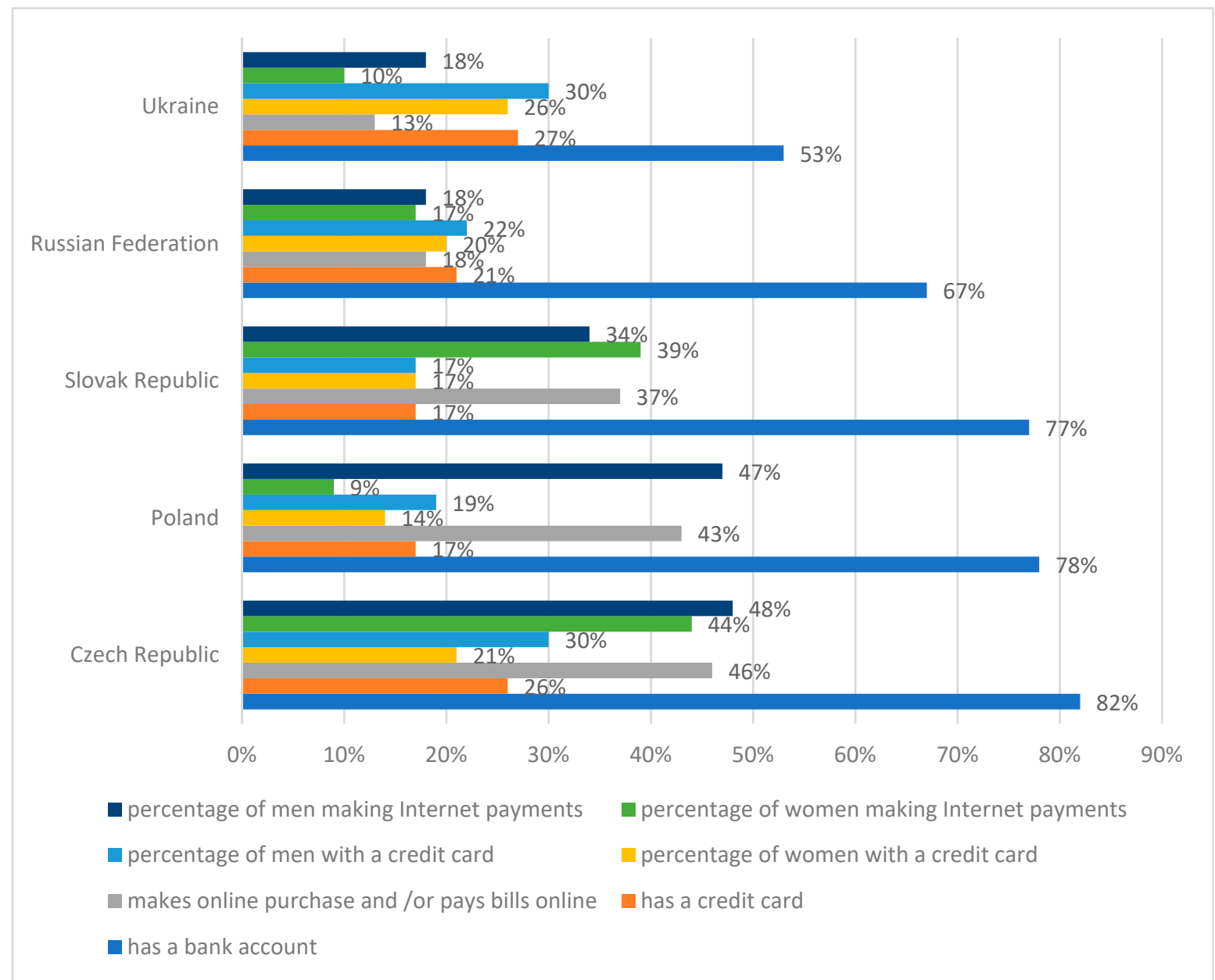

Figure 5. Internet and financial inclusion factors in chosen Central and Eastern European countries 2018. Source: developed by author based on We Are Social: Global Digital 2018.

Diversification of the rural economy was recognized as one of the key priorities in the Single and Comprehensive Strategy and Action Plan for Agriculture and Rural Development in Ukraine for 2015-2020. The strategy for rural areas development includes: development of the rural economy by stimulating non-agricultural operations, introducing innovative products, development of business networks, and increasing tourist potential for rural tourism development. 


\subsection{Prospects of ICT for Rural Development in Ukraine}

Advantages of ICT for rural stakeholders are recapitulated in the list of six main benefits: (1) e-trade of inputs and outputs; (2) extension and training activities for rural dwellers; (3) advertisement of rural tourism products; (4) knowledge transfer from urban to rural and vice versa; (5) official procedures; (6) geographic information system for management of natural resources (Akca et al. 2007, pp. 406-7).

E-trade of inputs and outputs in the case of agrarian business is considered to be problematic both in buying and selling (Akca et al. 2007). Ukraine's position in world agricultural production demands the application of modern development tools (Novak et al. 2020). However, ICT contributes to other sectors of economic growth and becomes essential for an innovative rural enterprise. Digitalization is an efficient tool supporting productivity increase in different branches of the economy, and digitalization of industry and business remains one of the keystones indicated in the strategy Digital Agenda for Ukraine 2020 (Novak et al. 2020).

Extension and training activities targeted at rural areas coincide with another key component of the Digital Agenda. Digital competence and skills help to constitute the knowledge-based society. The question of education and development is still the most important in terms of the formation of an information society. Information literacy, media literacy and technology literacy are listed among ten skills of the future (Synowiec 2020). ICT becomes an important factor in the process of equaling educational opportunities and helps to overcome the information gap. An example is the "Bibliomist" project-an initiative of Irex (global development and education organization operating in Ukraine in order to overcome digital and informational divides) together with the Ministry of Culture and Tourism, to help local communities in Ukraine by modernizing access to information in public libraries, providing 1500 libraries with equipment and training more than 1000 librarians to use modern technology tools and enabling them to assist citizens in obtaining information. The project was introduced in the period 2009-2014 with the aim of constituting the basis of digital culture in peripheral areas.

Rural inhabitants can benefit from the advertising of rural tourism products with a global reach (Akca et al. 2007). Digital marketing in Ukraine has been constantly evolving. A remarkable increase in social media users nationwide can be noticed-in 2020 the number of active social media users reached 19 million, which is $43 \%$ of the total population; according to estimates, 1.5 million new social media users have appeared since April 2019 and the number of people that can be reached with adverts on Facebook is evaluated as 13 million (Global Digital 2020). The increasing popularity of social networks implies potential for tourist product advertisement. The leader in terms of rural tourism development in Ukraine is the western region (Volyn, Zakarpattia, Ivano-Frankivsk, Lviv, Rivne and Chernivtsi regions), where the largest number of farmsteads offering touristic services is located. Rural tourism may contribute to rural areas' development in the following ways: (1) increasing income and employment rate in the rural population, (2) improving living conditions in the countryside, (3) establishing a positive image of Ukraine, (4) improving the infrastructure of villages, (5) supporting preservation of historical and cultural heritage (Diuk and Burlaka 2018). However, this issue of ICT's role in development of rural tourism in Ukraine has not been deeply recognized.

ICT in the urban-rural and rural—urban vectors of knowledge transfer can provide a solution to structural disparities. It is worth noting that public discourse is predominately constructed from the position of the cities-both in theory and practice (Wójcik 2009). Internet space allows the building of a bridge between rural and urban perspectives, which is important taking into account the development of human resources (Akca et al. 2007).

As for official procedures, the development of e-government in Ukraine was approved by the Decree of the Cabinet of Ministers of Ukraine in 2017 (Volik et al. 2019). E-government as a result of modernization of public administration provides access to public information and contributes to citizens' involvement in decision-making processes (Volik et al. 2019). In the case of rural dwellers, the question of digital competence is 
still relevant. The issues of information safety, cyber security, and data protection are prerequisite for cyber culture development (Novak et al. 2020).

The last dimension of ICT benefits for rural dwellers is the geographic information system (GIS) that can be applied to management of natural resources (Akca et al. 2007), wildlife protection or in culture heritage tourism. Disseminating knowledge by means of GIS may contribute to local and regional development.

Digitalization contributes to economic growth, productivity and efficiency increase (Kitchin 2015; Novak et al. 2020). As this results from discussing the social aspects of ICT in rural areas, the process of digitalization in Ukraine should be supported by "new forms of solidarity, partnership and cooperation" (Novak et al. 2020, p. 3432). Information and communication technologies are expected to provide equal opportunities in access to resources such as information and knowledge in order to improve life quality in peripheral areas. "Rural regions, although rich in natural and cultural resources, they are often seen as regions with certain deficits in knowledge capacity that constrain efficient exploitation of these resources" (Stratigea 2011).

With reference to the documents and analysis covering the role of ITC in rural development, the policy recommendations for rural areas in Ukraine are as follows:

(1) the recognition of the importance of knowledge as the most important factor in development and the integration of issues of knowledge distribution into national strategies (World Bank 1999; Scheerder et al. 2017);

(2) to consider the geographical context within the priority of developing space-oriented rather than sector-oriented policies (Chapman and Slaymaker 2002); to introduce a regionally sensitive perspective, based on the analysis of the needs and development strategy of the region, supported by new or already existing territorial strategies (Fajrillah et al. 2018);

(3) to develop tools to build human potential and synergy between some of the technological achievements, such as precision farming, the implementation of social services through digital platforms, circular economy, renewable energy, rural tourism and innovations in services and entrepreneurship (Bogovic and Szanyi 2018).

(4) the reduction of the knowledge gap in order to overcome underdevelopment-ICTs have the potential to address barriers to economic development by improving access to knowledge and information exchange (Chapman and Slaymaker 2002, p. 5);

(5) to develop "user-oriented knowledge and exchange strategies, targeted to address current and emerging needs of rural regions in transition" (Stratigea 2011);

(6) to mobilize local resources in order to solve encountered problems and take advantage of opportunities based on digital technologies, strengthen local community and improve partnerships (European Network for Rural Development 2017);

(7) the emergence of effective management tools and creating an environment that prevents corruption as a phenomenon (Digital Agenda for Ukraine 2020).

\section{Conclusions}

The aim of this study was to indicate and analyze the infrastructural and social aspects of dissemination of ICT in rural areas in Ukraine in comparison to other posttransition countries, in order to identify the current situation and the possibilities resulting from the spread of information and communication technologies for rural development. As emphasized by a number of scholars, the challenges arising from the shift from industrial to post-industrial paradigm apply likewise to rural areas (in terms of the improvement of economic performance or equalizing education opportunities and knowledge exchange, etc.). As far as information and communication technologies are considered an important factor of economic growth, their spread is unquestionably one of the conditions of smart development. The concept of smart or intelligent development may be applied to various types of spatial units, including rural areas. However, rural areas within the context of CEE and other former USSR countries are still more exposed to the consequences of different types of social exclusion due to geographical remoteness and infrastructural disadvantages. 
The course of study and collected materials revealed that dissemination of ICT in rural areas in Ukraine is influenced by two groups of factors-infrastructural and social. Both aspects were analyzed within the framework of socio-economic consequences of the post-communist transition period, regarding the measures chosen in other post-transition countries. Infrastructure still remains a sensitive area slowing down the use of ICT in rural areas in Ukraine. The digital divide concerning Internet access between rural and urban populations in Ukraine has been diminishing, but the issue of structural exclusion due to place of residence is current. Most of the available statistics on access to information and communication technologies indicate disparities between rural areas and cities. According to the estimations delivered by the largest country's provider, in Ukraine there are still 217,000 villages without access to the Internet. At the same time, the patterns of Internet consumption among urban and rural residents who have access to the Internet tend to be similar-rural residents use social networks, service platforms and make online payments. As pointed out by one of the domestic scholars, the problem is not a lack of need, but a lack of opportunity (Myskevych 2019). It is worth underlining that the infrastructural aspect concerning ICT dissemination in rural areas in Ukraine should be analyzed in a broader context: the rural-urban gap in Ukraine applies also to the question of healthcare access and educational services. Although the Ukrainian information technology industry has become an important branch in the structure of national export, the country is ranked in the lowest position among peer countries in terms of access to new technologies.

The social aspects of ICT dissemination in rural areas in Ukraine are no less important, since the level of digital literacy among rural residents is significantly lower in comparison to the urban population. Nationwide Ukrainian research conducted on digital literacy revealed that almost $60 \%$ of rural interviewees estimated their level of digital skills as "low" or "now skills". The structure of employment in rural areas should also be taken into account. Data obtained in a nationwide survey (2013) shows that $28 \%$ of rural inhabitants in Ukraine indicate agriculture as the main source of income. Therefore, developing tools to build human potential by means of the technological achievements and implementation of social services through digital platforms seems to be important for the further development of rural areas. The reduction of the knowledge gap in order to overcome underdevelopment, as well as in mobilizing local resources due to strengthening local communities, may contribute to the overcoming of the socio-cultural patterns inherited from the USRR.

Discussion concerning rural areas in post-Soviet countries is multidimensional. An outline of complex demographic, economic, and socio-cultural processes taking place in rural areas in Ukraine may contribute to establishing an interpretative framework for the question of smart development in former Soviet countries. The main prospects for further research with regard to the presented results may involve research both on socio-economic performance in rural areas (entrepreneurship, rural tourism, heritage tourism) and on social aspects (reduction of the knowledge gap, increasing the level of digital literacy).

Funding: This research received funding upon the project run by the Department of Applied Social Sciences: "Interdisciplinary research on the impact of cognitive technologies and artificial intelligence on the areas of Smart Human, Smart City, Smart Economy, Smart University, Smart Factory and Industry 4.0, Smart Management, Smart Crisis Management" (13/020/BK_20/0056).

Institutional Review Board Statement: Not applicable.

Informed Consent Statement: Not applicable.

Data Availability Statement: Data available in a publicly accessible repository.

Conflicts of Interest: The author declares no conflict of interest.

\section{References}

Agroportal.ua. 2018. Available online: http://agroportal.ua/publishing/konkurs/vopros-mesyatsa-pochemu-vazhno-razvivatukrainskoe-selo/ (accessed on 10 July 2020).

Akca, Hasan, Murat Sayili, and Kemal Esengun. 2007. Challenge of rural people to reduce digital divide in the globalized world: Theory and practice. Government Information Quarterly 24: 404-13. [CrossRef] 
Bajer, Malwina. 2012. Technologie informacyjno-komunikacyjne jako narzędzie ograniczania dysparytetów społeczno-ekonomicznych wsi w Unii Europejskiej. Wieś i Rolnictwo nr 1: 65-84.

Berkowska, Elżbieta, Hanna Rasz, and Stankiewicz Dorota. 2010. Infrastruktura techniczna wsi. Studia BAS Nr 4: 179-216.

Bogovic, Franc, and Tibor Szanyi. 2018. Bled Declaration for a Smarter Future of Rural areas in Europe. 2018. Available online: http:/ / pametne-vasi.info/wp-content/uploads/2018/04/Bled-declaration-for-a-Smarter-Future-of-the-Rural-Areas-inEU.pdf (accessed on 15 July 2020).

Boje, Carmen, and Nicolae George Dragulanescu. 2003. "Digital divide" in Eastern European countries and its social impact. Paper presented at 2003 ASEE Annual Conference and Exposition: Staying in Tune with Engineering Education, Nashville, TN, USA, June 22-25; ASEE Annual Conference Proceedings, pp. 9047-60.

Borodina, Olena, and Oksana Rykovska. 2020. Human capital evaluation and capitalisation specific to rural areas of Ukraine./Ocena kapitału ludzkiego i jego kapitalizacji na obszarach wiejskich na Ukrainie. Economic and Regional Studies 13: 58-69.

Buchowski, Michał. 2004. Redefining work in a local community in Poland "transformation" and class, culture and work. In Workers and Narratives of Survival in Europe: The Management of Precariousness at the End of the Twentieth Century. Edited by Angela Procoli. New York: State University of New York Press, pp. 173-96.

Campbell, Robert W. 1988. The Soviet Telecommunications System. Report to the National Council for Soviet and East European Research. Hudson Institute. Available online: https:/ / www.ucis.pitt.edu/nceeer/pre1998/1988-801-5-Campbell.pdf (accessed on 1 September 2020).

Campbell, Robert W. 2019. Soviet and Post-Soviet Telecommunications: An Industry Under Reform. Bloomington: Indiana University, United States.

Campbell, Scott W., and Nojin Kwak. 2010. Mobile Communication and Civic Life: Linking Patterns of Use to Civic and Political Engagement. Journal of Communication 60: 536-55. [CrossRef]

Chapman, Robert, and Tom Slaymaker. 2002. ICTs and Rural Development: Review of the Literature, Current Interventions and Opportunities for Action. Overseas Development Institute. Working Paper 192. London. Available online: https://www.odi.org/ sites/odi.org.uk/files/odi-assets / publications-opinion-files/2670.pdf (accessed on 1 September 2020).

Chreneková, Marcela, Melichová Katarina, Marišová Eleonora, and Moroz Serhiy. 2016. Informal employment and quality of life in rural areas of Ukraine. European Countryside 2: 135-46. [CrossRef]

Cowie, Paul, Townsend Leanne, and Salemnik Koen. 2020. Smart rural futures: Will rural areas be left behind in the 4th industrial revolution? Journal of Rural Studies 79: 169-76. [CrossRef]

Delgado García, Ana María, and Blanca Torrubia Chalmeta. 2016. Equalizing Educational Opportunities by ICT. International Conference e-Learning. Paper presented at the International Conference on E-Learning, EL 2016 - Part of the Multi Conference on Computer Science and Information Systems 2016, 2016 International Conference on E-Learning (EL 2016), Madeira, Portugal, July 1-4. Code 132156, pp. 211-14.

Delponte, Laura, Matteo Grigolini, Andrea Moroni, Silvia Vignetti, Massimiliano Claps, and Nino Giguashvili. 2015. ICT in the Developing World; Study IP/G/STOA/FWC/2013-001/LOT4/C3. Brussels: European Parliament.

Dema, Dmytro, Abramova Iryna, and Nedilska Larysa. 2019. Financial and economic conditions of rural development in Ukraine. Eastern Journal of European Studies 10: 199-220.

Digital Agenda for Ukraine. 2020. High Tech Office Ukraine. (org. in Ukrainian: Цифрова адженда України-2020). Available online: https: / / ucci.org.ua/uploads/files/58e78ee3c3922.pdf (accessed on 12 August 2020).

Diuk, Anna A., and Nelya I. Burlaka. 2018. Development of green tourism in Ukraine. Efektyvna Ekonomika. [CrossRef]

Dragulanescu, Nicolae George. 2002. Social impact of the "Digital Divide" in a Central-Eastern European Country. The International Information E Library Review 34: 139-51.

Dubov, Dmytro V., Mykola A. Ozhevan, and Serhiy L. Hnatyuk. 2010. Informatsiyne suspil'stvo v Ukrayini: Hlobal'ni vyklyky ta natsional'ni mozhlyvosti. Analitychna dopovid'. Natsional'nyy Instytut Stratehichnykh Doslidzen' Kyiv. (In Ukrainian). Available online: https://niss.gov.ua/sites/default/files/2011-02/dubov_infsus-31058.pdf (accessed on 10 November 2020).

Dzwigoł, Henryk, and Mariola Dzwigoł-Barosz. 2018. Scientific Research Methodology in Management Sciences. Financial and Credit Activity: Problems of Theory and Practice 2: 424-37.

European Bank for Reconstruction and Development. 2007. Transition Report 2007: People in Transition. Available online: https: //www.ebrd.com/downloads/research/transition/TR07.pdf (accessed on 15 July 2020).

European Network for Rural Development. 2017. Revitalising Rural Areas through Digitisation the Experience of Three Rural Digital Hubs. Working Document. Available online: https://enrd.ec.europa.eu/sites/enrd/files/tg_rural-businesses_case-study_ruraldigital-hub.pdf (accessed on 12 November 2020).

Eurostat. 2018. Eurostat Statistics on Rural Areas in the EU. Available online: https://ec.europa.eu/eurostat/statistics-explained/ index.php/Statistics_on_rural_areas_in_the_EU (accessed on 15 July 2020).

Factum Group Ukraine. 2019. Internet Coverage in Ukraine III Quarter of 2019. Available online: https://inau.ua/sites/default/files/ file/1910/dani_ustanovchyh_doslidzhen_iii_kvartal_2019_roku.pdf (accessed on 18 July 2020).

Fajrillah, Fajrillah, Zarina Mohamad, and Wirda Novarika. 2018. Smart city vs smart village. Jurnal Mantik Penusa 22: 1-6.

Fernandez-Portillo, Antonio, Manuel Almodovar-Gonzalez, Jose Luis Coca-Perez, and Hector V. Jimenez-Naranjo. 2019. Is Sustainable Economic Development Possible Thanks to the Deployment of ICT? Sustainability 11: 6307. [CrossRef] 
GFK Hungary. 2015. Democratic Attitudes in Ukraine. Available online: http:/ /archivesicdt.demkk.hu/documents / publications / Democratic-attitudes-in-Ukraine_2_eng.pdf (accessed on 18 July 2020).

Global Digital. 2018. We Are Social Global Digital 2018 Report. Available online: https://wearesocial.com/blog/2018/01/globaldigital-report-2018 (accessed on 18 July 2020).

Global Digital. 2020. We Are Social Global Digital 2020 Report. Available online: https:/ /wearesocial.com/digital-2020 (accessed on 18 July 2020).

Gorshenin Institute. 2013. The Socio-economic Situation of the Contemporary Ukrainian Village. Available online: http:/ institute. gorshenin.ua/researches/126_sotsialnoekonomichne_stanovishche.html (accessed on 18 July 2020).

Grimes, Seamus. 2003. The digital economy challenge facing peripheral rural areas. Progress in Human Geography 27: 174-93. [CrossRef]

Guzal-Dec, Danuta. 2018. Inteligentny rozwój wsi-koncepcja smart villages: Założenia, możliwości i ograniczenia implementacyjne. Studia Ekonomiczne i Regionalne 11: 32-49. [CrossRef]

Hromadske.ua. 2019. Do 2022 goda 90\% Ukrainy dolzhno imet dostup k 4G Internetu. Available online: https:/ / hromadske.ua/ru/ posts / do-2022-goda-90-ukrainy-dolzhno-imet-dostup-k-4g-internetu-pravitelstvo (accessed on 18 July 2020).

International Communication Union. 2020. Measuring Digital Development: Facts and Figures. Available online: https://www.itu. int/en/ITU-D/Statistics/Documents/facts/FactsFigures2020.pdf (accessed on 22 November 2020).

IT Ukraine Association and The Better Regulation Delivery Office. 2018. Development of Ukrainian IT Industry Analytical Report. Available online: https:/ /brdo.com.ua/wp-content/uploads/2018/12/IT_report_eng_F-1.pdf (accessed on 20 November 2020).

Janc, Krzysztof, and Konrad Ł. Czapniewski. 2013. The Internet as a development factor of rural areas and agriculture-Theory vs. practice. Studia Regionalia 36: 89-105.

Janc, Krzysztof, and Konrad Ł. Czapiewski. 2014. Internet jako czynnik poprawy sytuacji społecznej i ekonomicznej obszarów wiejskich. In Polityka Spójności UE a Rozwój Obszarów Wiejskich. Stare Problemy i Nowe Wyzwania. Edited by Wioletta Kamińska and Krystian Heffner. Warsaw: Studia KPZK PAN, vol. 156, pp. 195-218.

Jaska, Ewa. 2015. Dostępność i wykorzystanie technologii informacyjno-komunikacyjnych na obszarach wiejskich. Roczniki Naukowe Stowarzyszenia Ekonomistów Rolnictwa i Agrobiznesu 4: 110-15.

Jopek, Dorota. 2019. Intelligent urban space as a factor in the development of smart cities. Technical transactions. Architecture and Urban Planning 9: 5-15. [CrossRef]

Jorgenson, Dale W. 2005. Accounting for Growth in the Information Age. In Handbook of Growth Economics. Edited by Phillipe Aghion and Steven Durlauf. Amsterdam: North Holland.

Kaleta, Andrzej. 2016. Społeczeństwo Informacyjne na Obszarach Wiejskich. Toruń: Wydawnictwo Naukowe Uniwersytetu Mikołaja Kopernika.

Keyzar, Michiel A., Max Merbis, Rudolf Witt, Valeriy Heyets, Olena Borodina, and Prokopa Ihor. 2013. Farming and Rural Development in Ukraine: Making Dualization Work. Luxembourg: European Commission Joint Research Centre, Publications Office of the European Union.

Kirieieva, Eleonora, and Daruna Kostyuchenko. 2017. State and prospects of rural development in Ukraine. Baltic Journal of Economic Studies 3: 120-27. [CrossRef]

Kitchin, Rob. 2015. Making sense of smart cities: Addressing present shortcomings. Cambridge Journal of Regions, Economy and Society 8: 131-36. [CrossRef]

Komorowski, Łukasz, and Stanny Monika. 2019. (R)ewolucja wyposażenia wsi w wodę, prąd i telefon. In Ciagłość $i$ zmiana. Sto lat Rozwoju Polskiej wsi Tom 2. Warszawa: Instytut Rozwoju Wsi i Rolnictwa Polskiej Akademii Nauk; Wydawnictwo Naukowe Scholar, vol. 4, pp. 761-801.

Kos-Łabędowicz, Joanna. 2017. The issue of digital divide in rural areas of the European Union. Ekonomiczne Problemy Ustug 1: 195-204. [CrossRef]

Kuczabski, Aleksander, and Tomasz Michalski. 2013. The process of depopulation in the rural areas of Ukraine. Quaestiones Geographicae 32: 81-90. [CrossRef]

Kuzior, Aleksandra. 2010. Polskie i niemieckie doświadczenia w projektowaniu i wdrażaniu zrównoważonego rozwoju [Polish and German Experiences in Planning and Implementation of Sustainable Development]. Problemy Ekorozwoju—Problems of Sustainable Development 5: 81-89. (In Polish)

Kuzior, Aleksandra. 2014. Development of competences key to sustainable development. Scientific Papers of the Silesian University of Technology Organisation and Management 75: 71-81.

Kuzior, Aleksandra, and Alla Lobanova. 2020. Tools of Information and Communication Technologies in Ecological Marketing under Conditions of Sustainable Development in Industrial Regions (Through Examples of Poland and Ukraine). Journal of Risk and Financial Management 13: 238. [CrossRef]

Kuzior, Aleksandra, and Bartosz Sobotka. 2019. The role of social capital in the development of smart cities. Scientific Papers of the Silesian University of Technology Organisation and Management 134: 109-19. [CrossRef]

Liga.biznes. 2018. Tsifrovoy Razryv: Pochemu Ukrainskie sela Ostayutsya bez Interneta. May 15. Available online: https://biz. liga.net/all/telekom/article/tsifrovoy-razryv-pochemu-ukrainskie-sela-ostayutsya-bez-interneta (accessed on 18 July 2020). (In Russian)

Magosci, Paul Robert. 2017. Historia Ukrainy. Ziemia i Ludzie. Kraków: Księgarnia Akademicka. 
Maksymenko, Anna, and Tesliuk Roman. 2015. Downshifting as migratory phenomenon: The Ukrainian context. Psihologia i Suspil'stvo 2: 102-6. (In Ukrainian)

McKee, Martin, Dina Balabanova, K. Akingbadea, Pomerleaua Joceline, Andrew Stickleyb, Richard Rose, and Christian Haerpfer. 2006. Access to water in the countries of the former Soviet Union. Public Health 120: 364-72. [CrossRef] [PubMed]

Meijere, Sanita, and Tatiana Tambovceva. 2017. Information and communication technologies as enabler for rural development. Paper presented at Economic Science for Rural Development Conference, Jelgava, Latvia, April 27-28.

Ministry of Agrarian Policy and Food of Ukraine. 2015. Single and Comprehensive Strategy and Action Plan for Agriculture and Rural Development in Ukraine for 2015-2020. Available online: http:/ / extwprlegs1.fao.org/docs/pdf/ukr169405.pdf (accessed on 7 November 2020).

Ministry of Digital Infrastructure of Ukraine. 2019. Report on Digital Literacy of the Population of Ukraine. Available online: https: / / osvita.diia.gov.ua/uploads/0/588-the_first_in_the_history_of_ukraine_research_compressed.pdf (accessed on 7 November 2020).

Moroz, Serhiy. 2010. Changes in rural areas of Ukraine: Problems and opportunities. Paper presented at the 118th Seminar, Ljubljana, Slovenia, August 25-27.

Moroz, Serhiy. 2015. Employment in rural areas of Ukraine: Tendencies and opportunities. Studia Obszarów Wiejskich 38: 39-54. [CrossRef]

Murdoch, Jonathan. 2000. Networks-A new paradigm of rural development? Journal of Rural Studies 16: 407-19. [CrossRef]

Myskevych, Tetyana. 2019. Digital Inequality in modern society: Ukrainian dimension of global trends. Ukrainian Journal on Library and Information Science 3: 87-107. (In Ukrainian) [CrossRef]

Nam, Taewoo, and Theresa A. Pardo. 2011. Conceptualizing smart city with dimensions of technology, people, and institutions. Paper presented at ACM International Conference Proceeding Series 2011, 12th Annual International Digital Government Research Conference: Digital Government Innovation in Challenging Times, dg.o 2011, College Park, MD, USA, June 12-15; pp. $282-91$.

National Commission for the State Regulation of Communication and Informatization. n.d. Available online: https://nkrzi.gov.ua/ index.php? $\mathrm{r}=$ site $/$ index\&pg=1\&language $=\mathrm{uk}$ (accessed on 18 October 2020).

Navío-Marco, Julio, Beatriz Rodrigo-Moya, and Paolo Gerli. 2020. The rising importance of the "smart territory" concept: Definition and implications. Land Use Policy 99: 1-5. [CrossRef]

Nefedova, Tariana G., Irina Slepukhina, and Isolde Brade. 2016. Migration attractiveness of cities in the post-Soviet space: A case study of Russia, Ukraine, and Belarus. Regional Research of Russia 6: 131-43. [CrossRef]

Novak, Inna M., Oleksandr Y. Ermakov, Olesia A. Demianyshyna, and Alla A. Revytska. 2020. Digitalization as a vector of technological changes of Ukraine. International Journal of Scientific and Technology Research 9: 3429-34.

Pałka-Łebek, Ewa. 2017. Znaczenie agroturystyki w dochodowości gospodarstw rolnych na przykładzie Polski południowowschodniej. Ekonomiczne Problemy Turystyki 38: 85-94.

Pantyley, Victoria. 2009. Demographic Situation of Rural Population in Ukraine in the Period of Intensive Socio-Economic Transformation. European Countryside 1: 34-52. [CrossRef]

Park, Sora. 2017. Digital inequalities in rural Australia: A double jeopardy of remoteness and social exclusion. Journal of Rural Studies 54: 339-407. [CrossRef]

Philip, Lorna, and Fiona Williams. 2019. Remote rural home based businesses and digital inequalities: Understanding needs and expectations in a digitally underserved community. Journal of Rural Studies 68: 306-18. [CrossRef]

Pravo.ru. 2015. Телефонизировать“каждого рабочего и крестьянина” не удалось ни советской, ни российской власти (Neither Soviet nor Russian Authorities Succeeded in Telephoning "Every Worker and Peasant"). Available online: https:/ / pravo.ru/ news / view /119985/ (accessed on 18 July 2020).

Pro.Svit. 2020. Дослідження стану реалізації дистанційного навчання в Україні(березень-квітень2020). Available online: http:/ / prosvitcenter.org/pro-doslidzhennya (accessed on 18 July 2020).

Prozhivalsky, Oleg P. 1994. Development of Telecommunications in Ukraine. IEEE Communications Magazine 32: 42-43. [CrossRef]

Prytula, Khrystyna, Vitaliy Krupin, and Anna Maksymenko. 2014. Contemporary realities and Eurointegration prospects of rural development in Ukraine. Wieś i Rolnictwo 2: 83-99. [CrossRef]

Rakowski, Tomasz. 2016. Działania edukacyjne w przestrzeniach wsi. Odkrywanie podmiotowości środowisk wiejskich. In Nasze miejsce. Inspirator do pracy z lokalnościa. Edited by K. Kojder and E. Pajestka. Warszawa: Stowarzyszenie "Pracownia Etnograficzna" im. W. Dynowskiego, pp. 97-107.

Razumkov Center. 2014. Middle Class in Ukraine: Identification Criteria Expert Assessments, Citizen's Perceptions and Self-Identification. Kyiv. Available online: http:/ / fnst.org/sites/default/files/uploads/2016/08/02/1416488152file1.pdf (accessed on 15 July 2020).

Riznyk, Yulia. 2016. Organization and activity of rural post office of the right bank in the second half of the XIX-early XX century. Naukovi zapysky: Seriya Istoriya 1: 32-37. (org. In Ukrainian: Організація та діяльність сільської поштиПравобережжя в другій половині XIX-на початку XX ст., Наукові записки Тернопільського національного педагогічного університету іменіВолодимира Гнатюка. Серія: Історія).

Roberts, Bayard, Andrew Stickley, Alexander Gasparishvili, Christian Haerpfer, and Martin McKee. 2012. Changes in household access to water in countries of the former Soviet Union. Journal of Public Health 34: 352-59. [CrossRef] [PubMed]

Roman, Michał, and Arkadiusz Niedziółka. 2017. Agroturystyka jako Forma Przedsiębiorczości na Obszarach Wiejskich. Warszawa: Wydawnictwo SSGW. 
Salemink, Koen, Dirk Strijker, and Gary Bosworth. 2017. Rural development in the digital age: A systematic literature review on unequal ICT availability, adoption, and use in rural areas. Journal of Rural Studies 54: 360-71. [CrossRef]

Sarna, Arkadiusz. 2014. The transformation of agriculture in Ukraine: From collective farms to agroholdings. Centre for Eastern Studies Commentary Number 127. Available online: https:/ / www.osw.waw.pl/sites/default/files/commentary_127.pdf (accessed on 18 July 2020).

Scheerder, Anique, Alexander van Deursen, and Jan van Dijk. 2017. Determinants of Internet skills, uses and outcomes. A systematic review of the second- and third-level digital divide. Telematics and Informatics 34: 1607-24. [CrossRef]

Shah, Dhavan V., Nojin Kwak, and Robert L. Holbert. 2001. "Connecting" and "disconnecting" with civic life: Patterns of Internet use and the production of social capital. Political Communication 18: 141-62.

Shlyakhov, Oleksiy B. 2018. Formation and development of telephone communication in the Ukrainian lands of the Russian Empire in the late nineteenth and early twentieth centuries. History Grani 21: 51-61. (org. In Ukrainian: Становлення та розвиток телефонного зв'язку в українських землях Російської імперії наприкінці ХIX-початку XX ст.)

Shuldiner, Alec. 2020. The smart village. IEEE Pervasive Computing 19: 83-86. [CrossRef]

Skryzhevska, Yelizavieta, and David Karacsony. 2012. Rural population in Ukraine: Assessing reality, looking for revitalization. Hungarian Geographical Bulletin 61: 49-78.

Solnick, Steven L. 1991. Revolution, Reform and the Soviet Telephone System, 1917-1927. Soviet Studies 43: 157-75. [CrossRef]

Spoor, Max. 2011. Multidimensional Social Exclusion and the "Rural-Urban Divide" in Eastern Europe and Central Asia. Paper presented at Congress of the European Society of Rural Sociology 'Inequality and Diversity in European Rural Areas, Chania, Greece, August 22-25.

Spoor, Max. 2018. 25 Years of Rural Development in post-Soviet Central Asia: Sustaining Inequalities. Eastern European Countryside 24: 63-79. [CrossRef]

Spoor, Max, Luca Tasciotti, and Mihail Pelah. 2014. Quality of life and social exclusion in rural Southern, Central and Eastern Europe and the CIS. Post-Communist Economies 26: 201-19. [CrossRef]

Statistics Poland. 2016. Rural Areas in Poland 2016; Warszawa: Departament Badań Społecznych i Warunków Życia.

Statistics Poland. 2017. Sytuacja Społeczno-Ekonomiczna Gospodarstw Domowych: Zróżnicowanie Miasto wieś 2000-2015; Warszawa: Departament Badań Społecznych i Warunków Życia.

Stratigea, A. 2011. ICTs for Rural Development: Potential Applications and Barriers Involved. Networks and Communication Studies 25 3/4. Available online: https://journals.openedition.org/netcom/144?lang=en (accessed on 15 August 2020).

Sustainable Development Goals: Ukraine. 2017. National Baseline Report; Kyiv: Ministry of Economic Development and Trade of Ukraine. Available online: https://mfa.gov.ua/mediafiles/sites/poland/files/Sustainable_Development_Goals_Ukraine.pdf (accessed on 5 July 2020).

Synowiec, Aleksandra. 2018. Perspektywy i zagrożenia dla zrównoważonego rozwoju obszarów wiejskich na Ukrainie w świetle badań terenowych w obwodzie chmielnicki. Scientific Papers of the Silesian University of Technology Organisation and Management 129: 581-94.

Synowiec, Aleksandra. 2020. Global competence: A prerequisite for a global labor market and a challenge for education. Organization $\mathcal{E}$ Management. Scientific Quarterly 1: 129-37.

Sztompka, Piotr. 2000. Cultural trauma: The Other Face of Social Change. European Journal of Social Theory 3: 449-66. [CrossRef]

Sztompka, Piotr. 2004. The trauma of social change: A case of postcommunist societies. In Cultural Trauma and Collective Identity. Edited by Alexander C. Jeffrey, Ron Eyerman, Bernard Giesen, J. Neil Smelser and Piotr Sztompka. Berkeley: University of California Press, pp. 155-95.

Tussupova, Kamshat, Peder Hjorth, and Ronny Berndtsson. 2016. Access to Drinking Water and Sanitation in Rural Kazakhstan. International Journal of Environmental Research and Public Health 13: 1115. [CrossRef]

Ukrtelekom.ua. 2019. 15\% Naselennya Ukraini zhive v zoni Tsifrovogo Rozrivu. November 28. Available online: https:/ / ukrtelecom. ua/presscenter/15-naselennya-ukraini-zhive-v-zoni-tsifrovogo-rozrivu/ (accessed on 18 August 2020).

UNDP Ukraine. 2020. The Great Disruptor: How Covid-19 Is Nudging Ukraine towards Rapid Digital Transformation. July 7. Available online: https://www.ua.undp.org/content/ukraine/en/home/blog/2020/how-COVID-19-is-nudging-Ukrainetowards-digital-transformation.html (accessed on 18 August 2020).

US International Trade Commission. 1991. Central and Eastern Europe: Export Competitiveness of Major Manufacturing and Services Sectors; Investigation No. 332-308. Washington: US International Trade Commission.

van Dijk, Jan A. G. M. 2010. Społeczne Aspekty Nowych Mediów. Analiza Społeczeństwa Sieci. Warszawa: Wydawnictwo Naukowe PWN.

von Cramon-Taubadel, Stephan, and Sergiy Zorya. 2001. Policies and Agricultural Development in Ukraine, Aachen, Shaker Verlag. Available online: http:/ / pdc.ceu.hu/archive/00003447/01/Agrarbook_2001_eng.pdf (accessed on 18 July 2020).

Visvizi, Anna, Miltiadis D. Lytras, and Gyorgy Mudri. 2019. Smart villages: Relevance, approaches, policymaking implications. In Smart city in the EU and Beyond. Edited by A. Visvizi, M. D. Lytras and G. Mudri. Bingley: Emerald Publishing Limited, pp. 1-12. [CrossRef]

Volik, Vyacheslav, Yuliia Lozhmets, Olha Davydova, Svitlana Sprynchuk, and Dmytro Shvets. 2019. Electronic governance in Ukraine an Estonia current situation and prospectives. Journal of Legal, Ethical and Regulatory Issues 22: 1-5.

Wilkin, Jerzy, and Iwona Nurzyńska. 2018. Rural Poland 2018: The Report on the State of Rural Areas. Warszawa: Scholar Publishing House. 
Wójcik, Marcin. 2009. Wybrane koncepcje wsi we współczesnych badaniach geografii społecznej. Acta Universitatis Lodziensis Folia Geographica Socio-Oeconomica 10: 21-33.

Wójcik, Marcin. 2018. Koncepcja inteligentnego rozwoju (smart development)—wyzwanie dla planowania obszarów wiejskich. Acta Universitatis Lodziensis Folia Geographica Socio-Oeconomica 31: 5-15.

Wojnicka-Sycz, Elżbieta. 2013. Narzędzia ICT wspierające proces innowacyjny. Zarządzanie i Finanse 1: 403-17.

World Bank Group. 2019. Path for Ukraine's Economic Growth: Technology Upgrading. Available online: https://documents. worldbank.org/en/publication/documents-reports/documentdetail/880431575641119051/path-for-ukraines-economicgrowth-technology-upgrading (accessed on 18 July 2020).

World Bank Indicators. 2018. Available online: https:/ / data.worldbank.org/indicator/SP.RUR.TOTL.ZS?end=2018\&start=1960 \&view=chart (accessed on 18 July 2020).

World Bank. 1999. Knowledge for Development. World Development Report 1998-99. Oxford: Oxford University Press.

Yin, Ximing, Jin Chen, and Jizhen Li. 2019. Rural innovation system: Revitalize the countryside for a sustainable development. Journal of Rural Studies. [CrossRef]

Zakharova, Larissa. 2016. Was the Soviet telephone a medium of secondary orality? Some evidence from Soviet films of the 1930s-1970s. Russian Journal of Communication 8: 183-94. [CrossRef]

Ziemba, Paweł, and Jarosław Becker. 2019. Analysis of the Digital Divide Using Fuzzy Forecasting. Symmetry 11: 166. [CrossRef] 